\title{
CORPORATE SOCIAL RESPONSIBILITY PT. SEMEN TONASA DALAM PENANGANAN FAKIR MISKIN DI WILAYAH PESISIR DESA BULU CINDEA KABUPATEN PANGKEP SULAWESI SELATAN
}

\author{
Rachmat Parawangsa \\ Universitas Indonesia, rachmatparawangsa13@gmail.com \\ Indra lestari \\ Universitas Indonesia, inle_bon@yahoo.co.id
}

\begin{abstract}
This study discusses the implementation of empowerment of poor women's business groups thought PT Semen Tonasa's Corporate Social Responsibility (CSR) in the coastal area of Bulu Cindea Village, Pangkep Regency. The research was conducted with the aim of describing and improving information broadly and in dept( qualtitative descriptive) on the Onasa Mandiri Program in the form of training and procurement of womend's business groips. The research results provide a specific detailed description including; poverty condition, realization of the CSR fund budget, The TOnasa Mandiri Program, Impelmentation of community empowerment programs, as wel as obstacles to community empowerment.
\end{abstract}

Keywords:

Corporate Social Responsibility, community empowerment, poverty

\begin{abstract}
Abstrak
Studi ini membahas tentang implementasi pemberdayaan kelompok usaha perempuan miskin melalui Corporate Social Responsibility (CSR) PT Semen Tonasa di wilayah pesisir Desa Bulu Cindea Kabupaten Pangkep. Penelitian dilakukan dengan tujuan mendiskripsikan serta menggali informasi secara luas dan mendalam (kualitatif deskriptif) terhadap Program Tonasa Mandiri berupa pelatihan dan pengadaan kelompok usaha perempuan. Hasil penelitian menyajikan gambaran detail yang spesifik meliputi; kondisi kemiskinan, realisasi anggaran dana CSR, program Tonasa Mandiri, implementasi program pemberdayaan masyarakat, serta hambatan-hambatan dalam pemberdayaan masyarakat.
\end{abstract}

Kata Kunci:

Corporate Social Responsibility, pemberdayaan, masyarakat, kemiskinan

\section{PENDAHULUAN}

Kemiskinan merupakan masalah multi dimensi yang penanganannya membutuhkan kerjasama lintas sektor. Penanganan fakir miskin menjadi sebuah keharusan dalam rangka mengimplentasikan Undang-undang Nomor 13 Tahun 2011 tentang Penanganan Fakir Miskin. Penanganan fakir miskin dilakukan dengan mengalokasikan anggaran pendapatan dan belanja negara
(APBN/APBD) dan juga dana perusahaan perseroan. Perusahaan perseroan mewujudkan tanggung jawab ini dalam program Corporate Social Responsibility (CSR). Corporate Social Responsibility (CSR) diartikan sebagai komitmen dan kemampuan dunia usaha untuk memberi kepedulian, melaksanakan kewajiban sosial, membangun kebersamaan, melakukan program/kegiatan kesejahteraan sosial 
sebagai wujud kesetiakawanan sosial dan menjaga keseimbangan ekosistem disekelilingnya (Titisari, 2008). Sebagai Kabupaten dengan tingkat persentase kemiskinan terbesar di Sulawesi Selatan memberikan tekanan besar kepada PT. Semen Tonasa untuk tidak hanya mengambil keuntungan hasil alam namun juga diwajibkan memberi kesejahteraan bagi masyarakat setempat. Berikut ini tabel tingkat kemiskinan kabupaten pangkep.

Tabel 1. Tingkat Kemiskinan Kabupaten pangkep (2016-2019)

\begin{tabular}{|l|c|c|c|}
\hline Tahun & Kabupaten & $\begin{array}{c}\text { Penduduk } \\
\text { (jiwa) }\end{array}$ & Nasional \\
\hline 2016 & 16,22 & 52.680 & 10,70 \\
\hline 2017 & 16,22 & 53.400 & 10,12 \\
\hline 2018 & 15,10 & 50.120 & 9,82 \\
\hline 2019 & 14,06 & 47.070 & 9,41 \\
\hline
\end{tabular}

Sumber : Badan Pusat Statistik Tahun 2019

Jika dilihat dari tabel 1 diatas, kemiskinan Kabupaten Pangkep masih sangat jauh dari persentase nasional. Hal ini memerlukan usaha yang keras serta dukungan berbagai pihak dalam menurunkan angka kemiskinan minimal berada pada standar kemiskinan nasional yakni $9,41 \%$ pada tahun 2019. Kehadiran PT. Semen Tonasa sebagai produsen semen terbesar di kawasan timur yang terletak di Desa Biringere Kecamatan Bungoro Indonesia yang memiliki luas lahan sebesar 715 hektar diharapkan dapat memberikan kontribusi dalam berbagai sektor. Melalui Bidang CSR, PT Semen Tonasa melakukan berbagai aktivitas dalam beberapa program diantaranya.

PT Semen Tonasa dengan program Tonasa Bersaudara khususnya program Tonasa Mandiri dilaksanakan di Desa Bulu Cindea yang merupakan desa pesisir diharapkan dapat meningkatkan perekonomian atau pendapatan masyarakat. Beberapa program Tonasa Mandiri telah dilaksanakan di Desa bulu Cindea dari tahun 2016 sd 2018 tetapi belum pernah memberikan program tonasa mandiri berupa program kemitraan bantuan pinjaman modal atau dana bergulir.

Department of Foreign International Development (DFID) mempublikasikan kerangka mata pencaharian berkesinambungan

(Sustainable Livelihoods) sering dikaitkan dengan upaya pengentasan kemiskinan ataupun peningkatan kualitas hidup suatu komunitas (Adi, 2013). Kelompok usaha perempuan memberikan peluang tambahan penghasilan kepada komunitas perempuan dengan mengolah hasil laut berupa ikan olahan dan memberi nilai jual lebih tinggi kepada komoditas ikan bandeng tanpa duri.

Atas dasar uraian diatas, penelitian ini bertujuan untuk mengetahui "Bagaimana implementasi program Tonasa Mandiri dalam kegiatan pelatihan dan pengadaan kelompok usaha perempuan serta mengetahui hambatan-hambatan apa yang terjadi dalam program Tonasa Mandiri yang dilakukan dalam bentuk pelatihan dan pengadaan kelompok usaha perempuan".

\section{METODE}

Penelitian ini menggunakan pedekatan kualitatif dengan tujuan mendiskripsikan implementasi program Tonasa Mandiri berupa pelatihan dan pengadaan kelompok usaha perempuan. Penelitian dengan pendekatan ini berupaya menggali informasi secara luas dan mendalam dari para informan (Neuman, 2006). Jenis penelitian ini termasuk penelitian deskriptif karena menyajikan suatu gambaran detail yang 
spesifik dan informasi tersebut disusun, diolah serta dianalisa secara mendalam dan lengkap mengenai gejala dan fenomenanya. Informan terdiri dari 8 orang diantaranya; kepala seksi bina lingkungan, staf bina lingkungan, pelaksana program $C D$ Officer, forum CSR desa Bulu Cindea, Kepala desa Bulu Cindea, dan masyarakat penerima manfaat program.

\section{HASIL PENELITIAN}

\section{Kondisi Kemiskinan}

Kecamatan Bungoro terdiri dari 8 desa dan 7 diantaranya masuk kedalam Ring I PT Semen Tonasa dan sisanya berada di wilayah Ring 2. Di kecamatan ini terdapat dua desa pesisir yang terdiri dari Desa Bulu Cindea dan Desa Boriappakka. Jika dibandingkan dua desa pesisir yang berada di Kecamatan Bungoro maka Desa Bulu Cindea adalah desa dengan persentase kemiskinan terbesar. Penduduk miskin di Kecamatan Bungoro masih tergolong besar, hal tersebut dapat dilihat pada tabel berikut ini:

Tabel 2. Rumah Tangga Miskin di Kecamatan Bungoro, Tahun 2019

\begin{tabular}{|l|l|l|l|l|l|}
\hline No & Nama Desa & $\begin{array}{l}\text { Rumah } \\
\text { Tangga } \\
\text { Miskin }\end{array}$ & $\begin{array}{l}\text { Jumlah } \\
\text { Rumah } \\
\text { Tangga }\end{array}$ & $\%$ & Geografis \\
\hline 1 & Tabo-Tabo & 145 & 612 & $23,69 \%$ & $\begin{array}{l}\text { Non } \\
\text { Pesisir }\end{array}$ \\
\hline 2 & $\begin{array}{l}\text { Bowong } \\
\text { Cindea }\end{array}$ & 115 & 517 & $22,24 \%$ & $\begin{array}{l}\text { Non } \\
\text { Pesisir }\end{array}$ \\
\hline 3 & $\begin{array}{l}\text { Bulu } \\
\text { Cindea }\end{array}$ & 84 & 607 & $13,84 \%$ & Pesisir \\
\hline 4 & Mangilu & 84 & 681 & $12,33 \%$ & $\begin{array}{l}\text { Non } \\
\text { Pesisir }\end{array}$ \\
\hline 5 & Sapanang & 66 & 699 & $9,44 \%$ & $\begin{array}{l}\text { Non } \\
\text { Pesisir }\end{array}$ \\
\hline 6 & Boriappaka & 58 & 656 & $8,84 \%$ & Pesisir \\
\hline 7 & Samalewa & 35 & 917 & $3,82 \%$ & $\begin{array}{l}\text { Non } \\
\text { Pesisir }\end{array}$ \\
\hline 8 & Biring Ere & 24 & 338 & $7,10 \%$ & $\begin{array}{l}\text { Non } \\
\text { Pesisir }\end{array}$ \\
\hline
\end{tabular}

Sumber : SIKS NG Kementerian Sosial 2019

\section{Karakteristik Responden}

Sebagai industri besar dan Badan Usaha Milik Negara yang patuh terhadap peraturan Mentri BUMN tentang PKBL Kegiatan CSR Semen Tonasa terbagi menjadi tiga kegiatan. Berikut realisasi anggaran CSR PT Semen Tonasa sejak tahun 2016 hingga tahun 2019.

Tabel 3. Realisasi anggaran dana CSR PT Semen Tonasa 2016-2019 (dalam jutaan rupiah)

\begin{tabular}{|c|c|c|c|c|}
\hline \multirow{2}{*}{ Kegiatan } & \multicolumn{4}{|c|}{ ALOKASI DANA } \\
\hline & 2016 & 2017 & 2018 & 2019 \\
\hline $\begin{array}{l}\text { Program } \\
\text { Kemitraan }\end{array}$ & 12.700 & 12.965 & 13.253 & 60 \\
\hline $\begin{array}{l}\text { Program } \\
\text { Bina } \\
\text { Lingkungan }\end{array}$ & 5.000 & 4.796 & 3.758 & 3.995 \\
\hline $\begin{array}{l}\text { Tanggung } \\
\text { Jawab } \\
\text { Sosial } \\
\text { Lingkungan }\end{array}$ & 10.896 & 10.421 & 6.081 & 7.277 \\
\hline $\begin{array}{l}\text { Total } \\
\text { Anggaran }\end{array}$ & 28.596 & 28.183 & 23.093 & 11.333 \\
\hline
\end{tabular}

Sumber : Sustainability Report PT Semen Tonasa Tahun 2016-2019

Berdasarkan tabel diatas pada tahun 2016 anggaran berada pada angka 28.596.956.000 rupiah. Diantara keseluruhan tahun, tahun inilah yang mengalokasikan dana yang paling tinggi dibanding tahun-tahun sesudahnya. Tahun 2017 alokasi dana berada pada angka 28.183.203.000 rupiah, tahun 2018 alokasi anggaran 23.093.326.000 rupiah dan ditahun 2019 alokasi dana CSR hanya berada pada angka 11.333.031.000 rupiah. Tahun 2019 merupakan tahun dengan realisasi anggaran terkecil dalam kurun waktu 4 tahun terakhir. Adapun pendanaan bagi kelompok usaha perempuan ini masuk dalam salah satu bagian pada tahun 2018 dan 2019 pada dana kegiatan program bina lingkungan dengan realisasi dana 3.758721 .000 rupiah pada tahun 2018 dan 3.995.639.000 rupiah pada tahun 2019. 


\section{Program Tonasa Mandiri}

Desa Bulu Cindea yang merupakan desa pesisir yang merupakan salah satu objek lokasi dijalankannya program CSR PT Semen Tonasa. Program ini telah berjalan sejak tahun 2016 - 2019. Adapun programprogram yang dilaksanakan di desa ini, yakni sebagai berikut:

Tabel 4. Program Tonasa Mandiri

\begin{tabular}{|l|l|}
\hline Tahun & \multicolumn{1}{|c|}{ Program } \\
\hline 2016 & $\begin{array}{l}\text { 1. Pelatihan pertukangan } \\
\text { 2. Pelatihan jahit menjahit } \\
\text { 3. Pelatihan perbengkelan }\end{array}$ \\
\hline 2017 & $\begin{array}{l}\text { 1. Pelatihan dan bantuan alat salon } \\
\text { 2. Kelompok sewa menyewa tenda }\end{array}$ \\
\hline 2018 & $\begin{array}{l}\text { 1. Pelatihan dan pengadaan usaha } \\
\text { bandeng tanpa duri } \\
\text { 2. Pelatihan dan pengadaan alat } \\
\text { kelompok usaha souvenir }\end{array}$ \\
\hline 2019 & $\begin{array}{l}\text { 3. Kelompok usaha warkop } \\
\text { 2. Pengolahan kerupuk ikan }\end{array}$ \\
\hline
\end{tabular}

Sumber: Observasi dan wawancara Peneliti 2019

Program Tonasa mandiri yang penganggarannya dari program Bina lingkungan telah dimulai tahun 2016 terdiri dari pelatihan pertukangan, pelatihan menjahit/bantuan mesin jahit, pelatihan perbengkelan, dan pemberdayaan pemuda desa. Tahun 2017 dilaksanakan pelatihan zikir dan barazani, pelatihan dan bantuan alat sablon, kelompok usaha sewa menyewa tenda. Tahun 2018 bantuan kelompok usaha warkop, Pelatihan kepada kelompok perempuan, dan pelatihan dan pengadaan alat kelompok usaha souvenir.

Wilayah pesisir merupakan daerah pertemuan antara darat dan laut yang masih dipengaruhi kedua zona tersebut. Kawasan ini memiliki potensi sumber daya kelautan dan perikanan. Berdasarkan data BPS tentang statistik sumber daya laut Tahun
2018 wilayah pesisir memiliki fungsi transportasi dan pelabuhan, kawasan industri, agribisnis dan agroindustri, reksreasi dan pariwisata, serta kawasan pemukiman dan tempat pembuangan limbah. Kondisi ini sama dengan Desa Bulu Cindea yang masuk dalam 25 besar desa wisata dalam lomba desa wisata yang diadakan oleh kementerian Desa tahun 2019.

Melihat kondisi Desa Bulu Cindea yang merupakan desa pesisir yang memiliki potensi transportasi pelabuhan, kawasan industri karena berada di wilayah Ring 1 Semen Tonasa, potensi agribisnis yaitu tambak ikan, serta kerjasama pemerintah desa melalui dana desa dan Semen Tonasa dalam menjadikan Desa Bulu Cindea sebagai desa wisata tetapi angka kemiskinan masih tinggi padahal program pemerintah dalam bidang penanganan fakir miskin telah ada seperti Program Keluarga Harapan, Bantuan Pangan Non Tunai, dan Program kelompok usaha Bersama (KUBE). PT. Semen Tonasa berkontribusi untuk mengatasi kemiskinan di Desa Bulu Cindea melalui program CSR nya sejak 2016. Khususnya program Tonasa Mandiri yang berupa pelatihan, bantuan modal, serta pemberdayaan.

Adapun Kelompok Usaha Pemberdayaan Wanita dimulai sejak tahun 2018 dan tahun 2019. Adapun keseluruhan anggota kelompok merupakan warga miskin dan terdata dalam data terpadu kesejahteraan sosial (DTKS). Usaha perempuan tersebut terdiri dari: 
Tabel 5. Usaha Permberdayaan Perempuan

\begin{tabular}{|l|c|c|l|}
\hline Tahun & $\begin{array}{l}\text { Jumlah } \\
\text { Kelompok }\end{array}$ & $\begin{array}{l}\text { Jumlah } \\
\text { Anggota }\end{array}$ & Jenis Usaha \\
\hline 2018 & 2 & 20 & $\begin{array}{l}\text { Bandeng } \\
\text { Tanpa Duri }\end{array}$ \\
\hline 2019 & 2 & 22 & $\begin{array}{l}\text { Pengolahan } \\
\text { otak-otak dan } \\
\text { Kerupuk Ikan }\end{array}$ \\
\hline
\end{tabular}

Sumber: Data Peneliti, 2019

Berdasarkan tabel diatas pada tahun 2018 terdapat 20 anggota keluarga yang mendapatkan program usaha bandeng tanpa duri yang terdiri dari 2 kelompok sedangkan pada tahun 2019 program difokuskan pada pengolahan hasil laut berupa kerupuk ikan dan pengolahan makanan otak-otak yang melibatkan 22 anggota rumah tangga. Keseluruhan peserta ini adalah perempuan dan berasa dari keluarga miskin (prasejahtera).

\section{Program CSR PT. Semen Tonasa}

Rahmatullah (2011) mengemukakan usnsur pokok pelaksanaan CSR. Pertama adalah visi misi perusahaan, PT Semen Tonasa dengan visi menjadi perushaaan persemenan tekemuka di Indonesia yang efisien dan berwawasan lingkungan dengan salah satu misi meningkatkan nilai perusahaan sesuai keinginan stakeholder. CSR PT Semen Tonasa memiliki visi yaitu menjadi perusahaan persemenan dengan efisiensi yang tinggi dan berwawasan lingkungan di Indonesia dengan kinerja prima Bersama stakeholders dan berkontribusi pada pembangunan berkelanjutan. Strategi CSR PT Semen Tonasa prioritas di wilayah terkena dampak, mengatasi dampak operasi, memberikan manfaat dan bkeberlanjutan, focus pada program konsevasi energi yang mendukung ketahanan pangan, serta sosialisasi dan publikasi yang efektif. Melihat Struktur PT
Semen Tonasa, struktur CSR PT Semen Tonasa dan Visi Misi diatas serta strategi menjalankan CSR, jelas PT Semen Tonasa memiliki komitmen yang tinggi dalam melaksanakan program CSRnya, walaupun secara struktur unit CSR/Comdev Masih dibawah naungan Departemen Komunikasi dan hukum.

Wibisono (2007) mengemukakan alasan perusahaan melakukan CSR, melihat program CSR PT Semen Tonasa yaitu selain kepatuhan terhadap hukum peraturan perundang -undangan yang berlaku sebagai perusahaan plat merah. Sebagai anak perusahaan PT Semen Indonesia kewajiban terhadap UU 19 tahun 2003 tentang Badan usaha milik negara yang diwajibkan melaksanakan program kemitraan dan bina lingkungan serta UU 40 Tahun 2007 tentang Perseroan terbatas, tertuang pada pasal 74 menyatakan bahwa perseroan yang menjalankan usahanya di bidang dan atau berkaitan dengan sumber daya alam wajib melaksanakan tanggung jawab sosial dan lingkungan. Program penilaian peringkat kinerja perusahaan (proper) salah satu aspeknya adalah pengembangan masyarakat. Peraturan Menteri Lingkungan Hidup Nomor 6 Tahun 2013 mencamtumkan aspek struktur CSR perusahaan sebagai indicator penilaian.

PT Semen Tonasa mematuhi dengan adanya unit tersendiri yang mengurusi tentang CSR. PT Semen Tonasa melaksanakan CSR bukan hanya karena kepatuhan atas hukum tetapi melainkan tanggung jawab sosia 1 dan lingkungan. Hal ini dapat dilihat dari anggaran CSR yang dianggarkan terbagi menjadi 3 bagian yaitu anggaran program kemitraan dan program bina lingkungan sebagai kepatuhan terhadap hukum serta adannya anggaran tanggung 
jawab sosial lingkungan (TJSL). Anggaran ini sebagai pengaman jika ada program yang tidak dapat dianggarkan pada program kemitraan dan bina lingkungan. Hal ini menjawab masukan Wibisono (2007) bahwa selama ini program PKBL dibatasi terhadap lima objek bantuan bencana alam, pendidikan, Kesehatan, sarana dan umum dan ibadah. PT Semen Tonasa menyiapkan kantong anggaran yang dapat digunakan jika tidak dapat ditanggung oleh anggaran program kemitraan dan bina lingkungan.

CSR PT Semen Tonasa menetapkan blueprint sebagai manual book pelaksanaan program dengan mengambil tema Konservasi Energi Untuk Negeri, hal ini merupakan salah satu kritik Wibisono (2007) terhadap hal yang perlu dibenahi perusahaan dalam melaksanakan CSR

Pada dasarnya keberadaan CSR adalah untuk peningkatan dan memperkuat keberlanjutan suatu perusahaan dengan jalan membangun kerjasama antara stakeholder yang difasilitasi suatu perusahaan dengan menyusun

program-program kemasyarakatan untuk sekitar. Inilah yang menjadi esensi dari PT Semen Tonasa untuk mengimplementasikan program CSR sebagai wujud tanggungjawab sosial perusahaan dengan mengedepankan pertumbuhan khususnya bagi masyarakat di sekitar perusahaan. Hal ini sesuai pendapat Chappel and Moon (2005) dalam Crane (2014) bahwa perusahan- perusahaan di negara Asia seperti India, Thailand, Singapura, dan Malaysi dan Filiphina melaporkan CSR yang dilakukan di masyarakat lebih banyak dari pada di pasa dan ditempat kerja. Crane (2014) tipe tanggung jawab komunitas mengalami pergeseran dari sekdar filantropi menjadi filantropi strategis salah satunya membangun kemitraan lintas sector dengan kelompok masyarakat. Matten dan Crane (2005) dalam Crane (2014) strategi CSR di negara berkembang dengan mengambil tanggung jawab public menanganani kebutuhan masyarakat. Indonesia dengan adanya Undang Undang 13 Tahun 2011 tenatang penanganan fakir miskin, dana yang disisihkan perseroan meupakan salah satu sumber pendanaan dalam penanganan fakir miskin.

Dari hasil kajian, implementasi dari kemitraan dalam menjalankan program ekonomi yang berorientasi pada kemandirian masyarakat diperlukan bagi kelompok usaha di wilayah pesisir di Desa Bulu Cindea Kabupaten Pangkep. Dalam hal ini, penelitian ini lebih memfokuskan pada kelompok usaha perempuan. Hal ini dikarenakan perempuan merupakan bagian yang tak terpisahkan dari penyelenggaraan negara untuk membangun tatanan kehidupan bermasyarakat, berbangsa dan bernegara, serta mewujudkan kemajuan di segala bidang. Kondisi geografis dan kemiskinan menjadi persoalan tersendiri bagi perempuan untuk dapat mengakses berbagai kebutuhan mereka, terlebih untuk berpartisipasi dalam kegiatan-kegiatan publik. Perempuan lebih terfokus pada pemenuhan kebutuhan pokok diabandingkan terlibat dalam kelompok usaha. Sesuai pendapat Lister (2004) menyatakan bahwa kesmiskinan adalah kemampuan dalam memenuhi kebutuhan subsistence. Berbagai penyebab kemiskinan seperti gender yaitu orang tua tunggal dan kepala keluarga perempuan. Serr (2001) juga berpendapat bahwa ketidaksetaraan gender dapat menyebabkan kemiskinan. Kondisi demikian memberikan tantangan tersendiri 
bagi pemberdayaan kelompok usaha perempuan di wilayah tersebut.

\section{PEMBAHASAN}

Implementasi program pemberdayaan masyarakat melalui bina lingkungan yang dilakukan oleh PT Semen Tonasa sudah melalui tahapan proses pengembangan, mulai dari persiapan hingga evaluasi. Namun, untuk tahapan terminasi belum dilaksanakan cukup maksimal. Hal ini disebabkan oleh Grand Design yang ditetapkan oleh perusahan, yakni pembentukan kelompok usaha. Selain itu, terdapat beberapa kendala-kendala lain yang muncul dari temuan lapangan, yakni: (1) Kendala pelaku perubahan; (2) Kendala internal; (3) Kendala eksternal.

\section{Kendala Pelaku Perubahan}

Hekmatyar \& Nugroho, (2018) menjelaskan bahwa perkembangan sosial adalah hasil dari organisasi sosial dan sebagai suatu jenis dinamika di dalam organisasi sosial. Lembaga pembangunan merupakan kunci dari perkembangan sosial sebagai pelaku perubahan. Kendala pertama yang ditemukan dalam pelaksanaan program pengembangan masyarakat yang dilakukan PT Semen Tonasa adalah minimnya pengetahuan pendamping desa tentang pengembangan kelompok usaha. Selain itu beban kerja pendamping desa menjadi faktor penghambat dikarenakan ada dua desa yang harus didampingi dalam program CSR PT Semen Tonasa. Hal ini dapat dilihat dari salah satu program pengolahan hasil laut untuk pembuatan bandeng tanpa duri, pendamping desa kurang memberikan ide terkait strategi pemasaran. Kendala kedua terkait pelaku perubahan adalah sulitnya menjamin komunikasi tersampaikan dengan baik antara pendamping desa dengan kelompok usaha. Hal ini dikarenakan pertemuan antara pendamping dengan kelompok belum rutin dan sifatnya masih tentatif. Kendala ketiga terkait pelaku perubahan adalah sulitnya menjamin keberlangsungan pendamping desa dengan kelompok usahanya. Keterbatasan kemampuan fisik pendamping desa dalam melakukan kegiatan pendampingan untuk memastikan progres program CSR. Dimana pendamping desa membina dua desa, maka pendamping tersebut berfungsi sebagai pengontrolan. Beban kerja yang tidak sebanding dengan tenaga yang tersedia sehingga kerja pendamping desa tidak dapat fokus melaksanakan tugas pendampingan pemberdayaan masyarakat. Padahal kerja pendampingan desa, tidak hanya sebatas memastikan progress kegiatan CSR, melainkan ada kerja pemberdayaan untuk kemandirian dan kesejahteraan masyarakat. Aspek kualitas dalam pendamping desa terhadap materi pemberdayaan masyarakat. Penguasaan yang bersifat akademis dan teori-teori pemberdayaan mesti dikuasai dengan baik. Penguasaan materi pemberdayaan ini terletak pada beberapa hal, yaitu (1) tenaga pednamping desa mendapatkan materi pemberdayaan melalui pendidikan formal dan (2) melalui pendidikan dan pelatihan khusus. Selain penguasaan materi, keterujian penggunaan materi dengan penyelesaian masalah yang dihadapi juga menunjukan kualitas akademis individual. Pada aspek ini, ditemukan bahwa: (1) Tidak sesuainya latarbelakang keilmuan pendamping desa profesional dengan bidang kerja pendampingan dan pemberdayaan masyarakat sehingga ada kesulitan dalam pencapaian kompetensi kerja pendamping 
desa; (2) Minimnya pendidikan dan pelatihan yang dapat menambah wawasan, keilmuan dan penguasaan materi pemberdayaan masyarakat; (3) Membutuhkan proses dalam menginternalisasi pengetahuan sehingga pengetahuan itu menjadi kesadaran kerja sesuai bidang keilmuan pendampingan dan pemberdayaan masyarakat; dan (4) ada keterampilan pendukung kerja pendampingan desa yang harus dimiliki oleh pendamping desa profesional, sehingga urusan pendidikan (keilmuan) tidak terasupi oleh pendidikan saat pratugas.

\section{Kendala Internal}

Kendala internal yang ditemukan berkaitan dengan ketergantungan komunitas sasaran terhadap sesorang. Hal ini menjadi faktor penghambat dalam proses kemandirian kelompok usaha. Hal ini yang mengakibatkan proses pemandirian kelompok usaha menjadi melambat dikarenakan bergantung pada tokoh masyarakat. Hal ini juga berdampak pada penggalian potensi masyarakat yang juga bergantung pada tokoh tersebut. Hasil akhirnya adalah ide-ide program pemberdayaan masyarakat muncul berdasarkan kesepakatan tokoh masyarakat. Hal ini berbanding terbalik dengan kondisi sesungguhnya bahwa penggalian potensi seharusnya berasal dari ide-ide masyarakat melalui forum yang telah dibentuk. Hal ini juga mengakibatkan ketergantungan kelompok usaha kepada pendamping desa, dimana pendamping desa menginginkan pertemuan rutin, tetapi kenyataannya tidak dilakukan.

\section{Kendala Eksternal}

Kendala eksternal yang ditemukan secara umum berkaitan dengan kurangnya pemahaman masyarakat terhadap program CSR PT Semen Tonasa, program CSR masih belum menyentuh masyarakat yang paling membutuhkan, dan rendahnya komitmen dan semangat masyarakat dalam menjalankan program CSR. Hal ini disebabkan karena PT Semen Tonasa menggunakan mekanisme kerja bottom up sehingga tidak melakukan pengkajian mengenai analisis kebutuhan masyarakat di daerah pesisir. Salah satu keuntungan dari temuan lapangan adalah tokoh masyarakat yang mengusulkan program bergerak di bidang kelautan, sehingga program yang diusulkan tersebut berkaitan dengan budidaya ikan laut. Berikutnya adalah rendahnya komitmen masyarakat untuk berwirausaha, hal ini juga tidak lepas dari kurangnya minat dan motivasi kelompok usaha untuk memanfaatkan hasil pelatihannya dan membuat produk untuk dipasarkan. Kendala selanjutnya adalah ketiadaan intervensi perusahaan terkait pelatihan dan grand design yang masih terbatas pada pembentukan kelompok usaha menjadi faktor penghambat yang ditemukan dalam pemberdayaan masyarakat.

\section{KESIMPULAN}

Penelitian yang berjudul Implementasi Pemberdayaan Kelompok Usaha Perempuan di Wilayah Pesisir sebagai Corporate Social Responsibility PT Semen Tonasa di Desa Bulu Cindea Kabupaten Pangkep bertujuan untuk: (1) mendeskripsikan implementasi program Tonasa Mandiri pada kelompok usaha perempuan; dan (2) mendeskripsikan hambatan-hambatan apa yang terjadi dalam program Tonasa Mandiri pada kelompok 
usaha perempuan. Metode penelitian ini menggunakan pendekatan kualitatif dengan analisa data deskriptif yang disertai dengan data wawancara, studi dokumentasi, dan observasi.

Dari pembahasan terhadap temuan lapangan, dapat disimpulkan bahwa proses pelaksanaan program pemberdayaan masyarakat unit CSR PT Semen Tonasa dilakukan dalam enam tahapan. Pertama, tahap persiapan ditemukan bahwa sudah terbentuk forum CSR, pelibatan pendampingan desa, dan penyiapan lapangan/program diinisiasi oleh tokoh masyarakat yang bergerak di bidang laut. Kedua, tahap pengkajian ditemukan bahwa PT Semen Tonasa menggunakan mekanisme kerja bottom up terkait program kerja dan top down terkait dengan anggaran. Ketiga, tahap perencanaan dilaksanakan di tingkat forum CSR yang melibatkan aparat, pendamping desa, dan tokoh desa yang menginisiasi program. Keempat, tahap formulasi dilakukan proses penyusunan proposal rencana program, dimana masyarakat difasilitasi oleh forum CSR dan pendamping desa. Kelima, tahap pelaksanaan dilakukan kegiatan pelatihan pengolahan hasil laut, yakni: (1) pelatihan pembuatan bandeng tanpa duri; dan (2) pelatihan pembuatan otak-otak. Selain itu, pada tahap ini juga dibentuk kelompok usaha perempuan yang saat dalam tahap perintisan dengan nama forum "PERMATA". Keenam, tahap evaluasi ditemukan bahwa PT Semen Tonasa melakukan evaluasi terkait:

keterlaksanaan program yang diusulkan; (2) membandingkan realisasi kegiatan dengan rencana kegiatan (anggaran); (3) kesesuaian bahan yang diusulkan, apakah sudah sesuai spesifikasi atau tidak. Dalam pelaksanaan program pengembangan masyarakat, terdapat hambatan-hambatan apa terjadi dalam program Tonasa Mandiri pada kelompok usaha perempuan, diantaranya:

Pertama, kendala pelaku perubahan dalam pelaksanaan program pengembangan masyarakat, yakni: (1) minimnya pengetahuan pendamping desa tentang pengembangan kelompok usaha; (2) sulitnya menjamin komunikasi tersampaikan dengan baik antara pendamping desa dengan kelompok usaha; dan (3) sulitnya menjamin keberlangsungan pendamping desa dengan kelompok usahanya; Kedua, kendala internal berkaitan dengan ketergantungan komunitas sasaran terhadap sesorang, dimana kelompok usaha perempuan bergantung pada tokoh masyarakat dan ketergantungan kelompok usaha kepada pendamping desa. Ketiga, kendala eksternal yang ditemukan secara umum berkaitan dengan kurangnya pemahaman masyarakat terhadap program CSR PT Semen Tonasa, program CSR masih belum menyentuh masyarakat yang paling membutuhkan, dan rendahnya komitmen dan semangat masyarakat dalam menjalankan program CSR.

\section{DAFTAR PUSTAKA}

Adi, I. R. (2013). Intervensi Komunitas \& Pengembangan Masyarakat Sebagai Upaya Pemberdayaan Masyarakat (1 ed.). Rajawali Press.

Andriany, D., Hasibuan, L. S., \& Rahayu, S. E. (2018). Pengembangan model pendekatan partisipatif dalam memberdayakan masyarakat miskin kota Medan untuk memperbaiki taraf hidup. Kumpulan Penelitian dan Pengabdian Dosen, 1(1).

Ariefianto, L. (2015). Program Corporate Social Responsibility (CSR) PT Semen Indonesia Tbk Dan Dampaknya 
Terhadap

Masyarakat. Pancaran

Keberdayaan

Pendidikan, 4(2), 115-134.

Ariful, M. (2012). Persepsi Masyarakat Terhadap Partisipasi Mereka Dalam Program CSR Pt Holcim Indonesia Tbk-Cilacap Plant. Fakultas Ilmu Sosial dan Politik. Universitas Atma Jaya Yogyakarta.

Crane, A., Matten, D., \& Spence, L. (Eds.). (2019). Corporate social responsibility: Readings and cases in a global context. Routledge.

Hekmatyar, V., \& Nugroho, F. (2018). Badan usaha milik desa dan pembangunan sosial di kabupaten bojonegoro. Sosio Konsepsia, 7(3), 175-188.

Mawara, J. (2014). Bottom Up Planning Dalam Pembuatan Kebiiakan Pemerintah Desa Di Kecamatan Pineleng Kabupaten Minahasa. Jurnal Administrasi Bisnis (JAB), 4(027).

Murni, S., Amin, M. J., \& Fitriyah, N. (2017). Peranan Corporate Social Responsibility (Csr) Dalam Meningkatkan Pembangunan Masyarakat Desa Di Desa Lung Anai Kecamatan Loa Kulu. Jurnal Administrative Reform (JAR), 3(1), 138-147.

Neuman, W. L. (2006). Social research methods: Qualitative and quantitative research. University of Wisconsin.

Permen LH Nomor 06 Tahun 2013 Tentang Program Penilaian Peringkat Kinerja Perusahaan dalam Pengelolaan Lingkungan Hidup (PROPER).

Pranoto, A. R., \& Yusuf, D. (2014). Program CSR Berbasis Pemberdayaan Masyarakat Menuju Kemandirian Ekonomi Pasca Tambang di Desa Sarijaya. Jurnal Ilmu Sosial dan Ilmu Politik, 18(1), 39-50.

Raharjo, S. T., Humaedi, S., Wibhawa, B., \& Apsari, N. C. (2019). Memetakan Tokoh Masyarakat Untuk Kegiatan Csr Partisipatif. Share: Social Work Journal, 9(1), 37-48.

Rahmadani, R., Raharjo, S. T., \&
Resnawaty, R. (2018). Fungsi Corporate Social Responsibility (CSR) Dalam Pengembangan Dan Pemberdayaan Masyarakat. Share: Social Work Journal, 8(2), 203-210.

Rahmatullah, R. (2011, May). CSR dan Kepentingan Pemerintah Daerah. In Simposium Nasional Otonomi Daerah 2011. Universitas Sultan Ageng Tirtayasa.

Rinaldy, R., Nulhaqim, S. A., \& Gutama, A. S. (2017). Proses community development pada program kampung iklim di desa cupang kecamatan gempol kabupaten cirebon (studi kasus program bank sampah dalam program kampung iklim). Prosiding Penelitian dan Pengabdian kepada Masyarakat, 4(2).

Sumanti, S. (2020). CSR Pemberdayaan Masyarakat. Jurnal Sosial Soedirman.

Titisari, K. H. (2008). Corporate Social Responsibility (CSR) dan kinerja perusahaan. Universitas Sebelas Maret.

Undang-Undang Nomor 19 tahun 2003 tentang Badan Usaha Milik Negara.

Undang-Undang Nomor 40 Tahun 2007 tentang Perseroan Terbatas.

Undang-undang Nomor 13 Tahun 2011 tentang Penanganan Fakir Miskin.

Wibisono, Y. (2007). Membedah konsep \& aplikasi CSR: corporate social responsibility. Fascho Pub. 